https://doi.org/10.18485/iipe_regbezb.2021.ch2

\title{
KONCEPT INSULATORA U TEORIJI REGIONALNOG BEZBEDNOSNOG KOMPLEKSA
}

\section{Luka GLUŠAC ${ }^{1}$}

\begin{abstract}
Apstrakt: $\mathrm{U}$ fokusu ovog rada je koncept insulatora u teoriji regionalnog bezbednosnog kompleksa (TRBK), kao originalnog doprinosa Buzana i Vejvera studijama bezbednosti. Uvođenje koncepta insulatora bilo je neophodno kako bi se prevazišla teškoća u određivanju granica između regiona, odnosno kompleksa, odnosno kako bi se objasnilo različito delovanje jedinica (pre svega država) u odnosu na regionalni bezbednosni kompleks kojem ne pripadaju. Cilj ovog rada je propitivanje i dalja nadgradnja koncepta insulatora u TRBK, uvođenjem razlikovanja pasivnog i aktivnog insulatora. Pasivni insulator $\mathrm{u}$ ovakvoj podeli predstavlja tradicionalnog, odnosno uobičajenog insulatora koji razdvaja bezbednosne dinamike okolnih kompleksa, apsorbujući njihove energije. Za razliku od njega, aktivni insulator je onaj koji više emituje energiju, koji je važan činilac u bezbednosnim dinamikama susednih kompleksa, ali ne $\mathrm{u}$ dovoljnoj meri da ih ujedini u jedan jedinstveni. Pored doprinosa daljem razvijanju i preciziranju pojmovno-kategorijalnog aparata TRBK, uvođenje ovakve dihotomije ima i analitičko-prediktivnu funkciju jer postojanje aktivnog inuslatora sugeriše moguću transformaciju kompleksa, odnosno ukazuje na potencijal za integraciju ili dezintegraciju određenih (pod)regiona. Koncept insulatora se u radu težišno propituje razmatranjem statusa Turske u TRBK, dok se predložena klasifikacija insulatora inicijalno
\end{abstract}

\footnotetext{
${ }^{1}$ Naučni saradnik, Institut za filozofiju i društvenu teoriju, Beograd.

E-mail: luka.glusac@instifdt.bg.ac.rs.

Ovaj rad baziran je na master radu autora odbranjenog na Fakultetu političkih nauka Univerziteta u Beogradu. Rad je realizovan uz podršku Ministarstva prosvete, nauke i tehnološkog razvoja Republike Srbije prema Ugovoru o realizaciji i finansiranju naučnoistraživačkog rada.
} 
testira i kroz skiciranje primene na druge države koje su Buzan i Vejver klasifikovali kao insulatore.

Ključne reči: regionalna bezbednost, teorije bezbednosti, Buzan, Vejver, bezbednosni kompleks, potkompleks, insulator, tampon zona, turska spoljna politika.

\section{UVOD}

Promena globalne političke konstelacije izazvana implozijom Sovjetskog Saveza značajno je doprinela rekonceptualizaciji bezbednosti, koja je pak predstavljala epistemološki preduslov za pronalaženje adekvatnog pristupa za istraživanje bezbednosne zbilje. Završetkom velike bipolarne utakmice, regionalni odnosi su doživeli ekspanziju te je regionalistička perspektiva postala sve značajnija u savremenim studijama bezbednosti.

Pretpostavka da u XXI veku na sistemskom nivou (svetskoj sceni) operišu globalne i velike sile, a na podsistemskom regionalne sile i regioni, razrađena je u teoriji regionalnog bezbednosnog kompleksa (dalje u tekstu: TRBK) koju su postavili predstavnici Kopenhaške škole Beri Buzan (Barry Buzan) i Ule Vejver (Ole Waever). Osnovna ideja ovakve postavke je uzimanje $\mathrm{u}$ obzir regionalnih podsistema kao objekata bezbednosne analize. TRBK, za razliku od većine drugih teorija, dakle, ne zanemaruje regionalni nivo bezbednosti već ga naglašava i to zastupajući pristup "odozdo-nagore".

TRBK polazi od toga da je regionalni nivo najbolji za razumevanje bezbednosti. Nudeći analitički okvir za proučavanje bezbednosti na regionalnom nivou, ona nastoji da istakne relativnu autonomiju bezbednosnih odnosa u okviru datog regiona. Ona, takođe, istraživačima nudi jasan jezik i koncepte kako bi mogli da komparativno analiziraju regionalnu bezbednost. Teorija regionalnog bezbednosnog kompleksa nudi odgovarajući analitički okvir koji naglašava relativnu autonomiju regionalnih bezbednosnih interakcija unutar kruga jedinica koje formiraju regionalni bezbednosni kompleks.

Buzan i Vejver su, u pokušaju da kreiraju sveobuhvatnu teoriju a uviđajući heterogenost odnosa između jedinica i specifičnosti bezbednosne dinamike $\mathrm{u}$ različitim delovima sveta, uveli u svoju teoriju nekoliko pojmova kako bi objasnili različito delovanje jedinica (pre svega država) 
u odnosu na regionalni bezbednosni kompleks (RBK) kojem ne pripadaju. Ovo im je, s jedne strane, pomoglo u odbrani jednog od osnovnih postulata teorije (da jedna jedinica može biti član samo jednog RBK), dok je, s druge, donelo inovativnost $u$ smislu uvođenja novih pojava (a time i pojmova) $u$ studije bezbednosti.

Buzan i Vejver kao početnu tačku analize uzimaju to da ceo svet može da se podeli na međusobno isključive (razgraničene) regionalne bezbednosne komplekse, države insulatore i globalne aktere. Regionalni bezbednosni kompleksi se razlikuju jedan od drugog po stepenu bezbednosne povezanosti i nezainteresovanosti (engl. indifference), a od globalnih sila po tome što su smešteni na različitom nivou analize. Spoljašnja umešanost se analizira upotrebom termina prodiranje (engl. penetration) i prekrivanje (engl. overlay). Penetracija ili prodiranje podrazumeva prisustvo neke globalne sile u nekom regionu (Ejdus and Kovačević 2019). Pod prekrivanjem se podrazumeva prisustvo i kretanje jedne ili više sila $u$ nekom regionu, sa efektom gušenja unutrašnje bezbednosne dinamike. ${ }^{2}$ Ova situacija se razlikuje od normalnih procesa mešanja velikih sila u dinamiku regionalnih bezbednosnih kompleksa. Teškoća u određivanju granica između regiona može biti prevaziđena primenom asimetrije gde se susedna velika sila naslanja na slabiji susedni RBK ili uočavanjem države insulatora.

Upravo će se $\mathrm{u}$ centru ovog rada naći priroda insulatora $\mathrm{u}$ teoriji regionalnog bezbednosnog kompleksa. U radu će se, dakle, proveravati sam koncept i njegova upotrebna vrednost u TRBK. Na osnovu toga će se ponuditi dihotomna klasifikacija insulatora, kao pomoćno analitičko i prediktivno sredstvo u TRBK. Predlaže se, dakle, inovacija teorije regionalnog bezbednosnog kompleksa uvođenjem bližih određenja pasivni insulator i aktivni insulator. Pasivni insulator $\mathrm{u}$ ovakvoj podeli predstavljao bi tradicionalnog, odnosno uobičajenog insulatora koji

\footnotetext{
${ }^{2}$ Tokom Hladnog rata postojao je overlay SAD i SSSR u Evropi i iz tog razloga nije postojala unutrašnja bezbednosna dinamika. Evropa je bila, i s jedne i s druge strane, prekrivena i evropski bezbednosni problemi su zapravo bili problemi između dva bloka. Svi problemi u vezi sa proliferacijom konvencionalnog i nuklearnog naoružanja, kao i START, SALT i drugi sporazumi su bili sklopljeni između SAD-a i SSSR-a, kako ne bi došlo do sukoba u Evropi - poprišta sučeljavanja tih blokova. U tom slučaju nema RBK jer nema interevropskih regionalnih bezbednosnih dinamika, već globalnih.

${ }^{3}$ Insulator na engleskom jeziku, između ostalog, znači i izolator.
} 
razdvaja bezbednosne dinamike okolnih kompleksa, apsorbujući njihove energije. Dakle, imao bi klasičnu ulogu izolatora. ${ }^{3}$ Za razliku od njega, aktivni insulator bio bi onaj koji više emituje energiju, ali ne $u$ dovoljnoj meri da ujedini različite komplekse u jedan jedinstveni.

Razlog više za uvođenje podele insulatora je i to što bi ovakvim pristupom postojanje aktivnog inuslatora sugerisalo moguću spoljašnju transformaciju kompleksa. Tako bi on predstavljao indikator i pomogao $\mathrm{u}$ predviđanju daljih kretanja i promena na mapi regionalnih bezbednosnih kompleksa. Zbog ograničenog obima rada, koncept (aktivnog) insulatora biće primarno proveravan na primeru Turske, dok će se ponuditi skica za ostale insulatore, kao podložak za potencijalne dalje temeljnije studije slučaja.

Rad počinje pregledom glavnih odlika teorije regionalnog bezbednosnog kompleksa da bi se potom prešlo na predstavljanje esencijalne strukture i tipove kompleksa kao neophodne osnove za razmatranje koncepta insulatora $u$ TRBK. Nastavak rada se fokusira na primer Turske kao specifičnog insulatora. Turska se koristi i kako bi se testirala ideja o bližem određivanju insulatora kroz njihovo označavanje kao aktivnih ili pasivnih. Pre nego što se rad sumira u zaključku, inovativna insulatorska dihotomija se ukratko primenjuje na druge primere insulatora $\mathrm{u}$ TRBK.

\section{KLJUČNE ODLIKE TRBK}

Iako se ne može reći da polje regionalne bezbednosti nije dovoljno akademski tematizovano, čini se da su dosadašnje studije ove problematike mahom bile preuske i zastarele (pre svega one pisane za vreme Hladnog rata), ili im, što je najčešće slučaj, nedostaje adekvatan konceptualni aparat. Tako se tradicionalno najveći deo autora fokusirao na uzroke regionalnog mira (Deutsch 1957; Jervis 1989; Keohane 1984; Morgenthau 1984; Mearsheimer 2001), ili na pojavu regionalnih zona mira (Singer and Wildavsky 1993; Kacowicz 1997; Gleditsch 2002), te ulogu regionalnih organizacija u prevenciji konflikata i kriznom menadžmentu (Diehl and Lepgold 2003; Pugh and Sidhu 2003; Graham and Felıcio 2006). Više istaknutih autora bavilo se integracijom država (Haas 1958; Mitrany 1966; Nye 1971), ili pak oblasnim studijama, odnosno bezbednosnim šablonima u specifičnim regionima (Ngoma 2005; Antonenko 2008). TRBK je prvi put 
predstavio Buzan u prvom izdanju dela People, States and Fear 1983. godine. Teorija je primenjena na Južnu Aziju i na Bliski istok (Buzan 1983), a zatim razrađena i dublje primenjena na slučaj Južne Azije (Buzan and Rizvi 1986), a kasnije i na Jugoistočnu Aziju. Vajrinen (Väyrynen) (1984; 2003) i Ajob (Ayoob) (1999) primenjivali su teoriju na nekoliko regionalnih slučajeva. Buzan i Vejver (2003) kasnije razrađuju teoriju u knjizi Regions and Powers iz 2003. godine, koja će predstavljati glavni izvor ovog rada.

Kako i sam naziv teorije upućuje, kao osnovnu analitičku jedinicu svog pristupa Buzan i Vejver uzimaju regione, odnosno oni konceptualizuju regionalni bezbednosni kompleks. Oni su regionalni bezbednosni kompleks prvo predstavili kao "grupu država čiji su primarni bezbednosni interesi toliko usko povezani da se njihove nacionalne bezbednosti ne mogu realistično razmatrati odvojeno" (Buzan 1983, 106), da bi uviđanjem mogućnosti da se kao referentni objekti mogu uzeti drugi akteri osim države, definicija je doživela reviziju u pomenutoj sveobuhvatnoj studiji Regions and Powers, koja sada glasi: „skup jedinica čiji su glavni procesi sekuritizacije i desekuritizacije toliko povezani da se njihovi bezbednosni problemi ne mogu razumeti odvojeno" (Buzan and Wæver 2003, 44).

TRBK je teorija "srednjeg puta“ nastala kao odgovor na treću veliku debatu $\mathrm{u}$ teoriji međunarodnih odnosa. Stoga predstavlja kombinaciju materijalističkog i konstruktivističkog pristupa. Sa materijalističke strane koristi ideje ograničene teritorijalnosti i raspodele moći koje su slične onima u neorealizmu (s jasnom razlikom da se neorealističke analize isključivo koncentrišu na globalni nivo strukture). Sa konstruktivističke - TRBK se zasniva na teoriji sekuritizacije koja objašnjava odnose prijateljstva i neprijateljstva, odnosno socijalnu konstruisanost pretnji. Njen centralni koncept, esencijalna struktura, materijalno je i konstruktivistički razgraničena, primećuje Oskanijan (Oskanian) - „Kompleksi su definisani anarhijom i polaritetom, granice određene putem bezbednosne međuzavisnosti i intersubjektivnih modela prijateljstva i neprijateljstva; štaviše, ona sadrži u sebi i elemente strukture (materijalne i ideacione) i procesa (sekuritizacija)“ (2008, 2). RBK su, dakle, socijalno konstruisani regioni, u smislu da zavise od bezbednosne prakse konstituišućih aktera, te je u TRBK prvenstveno reč o „proučavanju bezbednosnih diskursa i bezbednosnih praksi aktera, a ne primarno (kurziv $u$ originalu, prim.aut.) njihovih regionalnih diskursa i praksi“ (Buzan and Wæver 2003, 48), mada Buzan i Vejver priznaju da se i oni uzimaju u obzir. Prema tome, pristup TRBK je konstruisan oko bezbednosti i bezbednost je ono što akteri čine, a 
na analitičaru je da uoči i mapira te prakse. S obzirom na to da je fokus na diskursu i praksi, koji su po definiciji promenljive kategorije, RBK su „pre trajni nego nepromenljivi modeli“ (Buzan and Wæver 2003, 50). Kompleksi će uvek biti prisutni kao podstrukture $u$ međunarodnom sistemu, ali ne $\mathrm{u}$ istom sastavu, zbog mogućnosti transformacije.

Prema TRBK, članstvo u regionima je međusobno isključivo, tj. jedna država ne može biti član više regiona, po čemu se TRBK razlikuje od teorije Morgana i Lejka iznetoj u knjizi Regional Orders: Building Security in a New World 1997. godine. Takođe, za razliku od Kacenštajnove studije World of Regions: Asia and Europe in the American Imperium (2005) koja se usredsređuje na istraživanje dva regiona, Evrope i Azije, i nudi epistemološki drugačiji pristup (Kacenštajn posmatra regione spolja i pritom mu je dominantan pristup u pogledu građenja regiona onaj "odozgo-nadole“ $),{ }^{4}$ TRBK pokušava da obuhvati sve regione sveta $i$, kako je pomenuto, predstavlja jednu od retkih teoretizacija s pristupom "odozdo-nagore“.

Važna odlika ove teorije je teritorijalnost, kako Buzan i Vejver smatraju da većina pretnji putuje mnogo lakše (brže) preko kraćih distanci nego preko dugih, pa je stoga bezbednosna međuzavisnost uglavnom utvrđena unutar regionalno grupisanih klastera: bezbednosnih kompleksa. ${ }^{5}$ Jasno je, na kraju, da TRBK svoju logiku o bezbednosnim regionima zasniva na činjenici da je bezbednost relacione prirode. Stoga se, kaže Buzan, „, ne može razumeti nacionalna bezbednost bilo koje države ukoliko se ne razume međunarodni obrazac bezbednosne međuzavisnosti u kojoj je bezbednost te države ugrađena" (Buzan 1983, 187).

\section{Bezbednosna konstelacija i uslovi za postojanje kompleksa}

TRBK služi kao okvir koji organizuje empirijske studije regionalne bezbednosti, smeštajući komplekse na regionalnom nivou unutar okvira za analizu koji se sastoji od četiri nivoa koji se prostiru od države, preko

\footnotetext{
${ }^{4}$ Naime, on je „svet regiona“ predstavio kao određen jednom jedinom silom. Svet regiona za njega oblikuje samo moć Sjedinjenih Američkih Država. Isključivo je moć ove države bitna. Kacenštajn drži da je tako zato što su samo SAD globalno uspostavile svoje prisustvo. Ovakva vrhovna moć SAD je u njegovoj teoretizaciji dobila rimski naziv „imperium“ (imperijum).

${ }^{5}$ Fridberg je na istom tragu kada kaže da je „većina država tokom istorije bila primarno zabrinuta zbog mogućnosti i namera njihovih suseda“" (Friedberg 1990, 168).
} 
regionalnog i međuregionalnog, do globalnog nivoa. Nivoi analize su: unutrašnja bezbednost, odnosi između država u regionu, odnos regiona sa susednim regionima i uloga globalnih sila u regionu (Buzan and Wæver 2003, 51).

Pod unutrašnjom bezbednošću misli se na unutrašnje stanje $u$ državama regiona, posebno njihove unutrašnje slabosti. Da li je država jaka ili slaba zavisi od stabilnosti unutrašnjeg poretka i korespondencije između države i nacije. Posebno, ranjivost države definiše vrstu bezbednosnih strahova koje ima, i ponekad čini drugu državu ili grupu država strukturalnom pretnjom čak i ako one nemaju neprijateljske namere.

Pod odnosima između država u regionu podrazumevaju se odnosi koji stvaraju region kao takav, dok je odnos regiona sa susednim regionima generalno manje značajan, jer je u TRBK kompleks definisan unutrašnjom interakcijom koja je mnogo važnija. Ako su glavne promene u modelima bezbednosne međuzavisnosti koje definišu region u toku, ovaj nivo može postati značajan. Konačno, uloga globalnih sila u regionu podrazumeva uzajamno dejstvo struktura globalne i regionalne bezbednosti. Koji će nivo biti dominantan zavisi od slučaja do slučaja.

Ova četiri nivoa analize konstituišu bezbednosnu konstelaciju. Ovo treba uzeti sa rezervom, jer je bezbednosna konstelacija širi koncept od bezbednosnih kompleksa pošto odražava ukupnost mogućih bezbednosnih odnosa na svim nivoima. O bezbednosnoj konstelaciji treba misliti kao o konceptu koji nije samo u vezi sa bezbednosnim kompleksima, već je u vezi sa čitavim okvirom čiji su oni deo (Buzan, Weaver and de Wilde 1998, 201). Buzanova i Vejverova ideja je bila da se odvoje pomenuta četiri nivoa za potrebe analize i da se potom sastave zajedno kako bi se stvorila potpuna slika. Ratio teorije RBK je da će regionalni nivo uvek biti operativan, a ponekad dominantan. Drugim rečima, regionalni nivo se uvek mora uzeti u obzir, zato što su sva četiri nivoa bezbednosne konstelacije istovremeno i uvek „u igri“.

Iako je regionalni nivo uvek $\mathrm{u}$ igri, potrebno je da se ispune određeni (pozitivni i negativni) uslovi da bi uopšte mogli da postoje RBK. Buzan i Vejver smatraju da je nužno da jedinice budu teritorijalno fiksirane jedinice. Kako su glavne jedinice u TRBK države - uvek fiksirane, a ne mobilne ovaj uslov je lako ispuniti. Drugi pozitivni uslov je postojanje anarhične strukture međunarodnih odnosa. Kako ne postoji jedan vrhovni autoritet koji upravlja ostalim političkim zajednicama, ni ovaj uslov nije neizvestan. $\mathrm{Na}$ kraju, potrebne su (velike) geografske distance između RBK. Iako 
tehnološki napredak u praksi smanjuje distance između kompleksa i dalje su glavni kompleksi razdvojeni okeanima.

Pored ovih pozitivnih, potrebno je da se ispune i negativni uslovi. Prvi je da ne postoji autarhija, odnosno samozaokupljenost unutrašnjim stvarima. U današnjem, globalizovanom, svetu ovo je nemoguće. Druga dva uslova koja mogu da dovedu do neformiranja RBK su postojanje "prekrivača“ (engl. overlay) ili "nestrukturiranog“ (engl. unstructured) regiona, odnosno situacije da regionalni nivo ne funkcioniše zato što lokalni akteri ne proizvode modele bezbednosne međuzavisnosti. Kako je prekrivanje već spomenuto, valja objasniti šta se podrazumeva pod nestrukturiranim bezbednosnim regionima. Oni nastaju iz dva razloga: prvog, kada lokalne države imaju slabu sposobnost da projektuju moć van svojih granica i, drugog, kada geografska izolacija čini interakcije teškim (ostrva okružena okeanima) (Buzan and Wæver 2003, 62). Obe situacije mogu rezultirati stvaranjem nedovoljne bezbednosne međuzavisnosti koja je neophodna za formiranje strukture RBK. Prema tome, u slučaju prekrivanja, bezbednost regiona je definisana spoljašnjim silama. U slučaju nestrukturiranih regiona, oni su delom određeni odsustvom regionalnih dinamika a delom nepovoljnim prostorom. ${ }^{6}$ Uvođenjem ovih mogućnosti i uslova, Buzan i Vejver uspevaju da popune svetsku mapu koristeći TRBK.

\section{Esencijalna struktura i evolucija kompleksa}

Bezbednosni kompleksi kao osnovne jedinice u TRBK imaju svoju esencijalnu strukturu, kako je nazivaju Buzan i Vejver. Svaki kompleks može se sagledati kroz četiri osnovna elementa te esencijalne strukture: granice, anarhičnu strukturu, polaritet i socijalnu konstruisanost (Buzan and Wæver 2003, 53). Pod granicom se podrazumeva linija razdvajanja konkretnog RBK i okolnih (ostalih) kompleksa. Granica je promenljiva kategorija jer njenim pomeranjem dolazi do transformacije RBK. Drugi element je anarhična struktura, što znači da kompleks mora biti sastavljen od dve ili više jedinica. Drugim rečima, reč je o postojanju ili nepostojanju diferenciranosti odnosa između jedinica koje tvore kompleks. Već je rečeno da TRBK uzima kao

\footnotetext{
${ }^{6}$ Postavlja se pitanje kada bezbednosna interakcija postaje dovoljno intenzivna za početak stvaranja regionalne bezbednosne podstrukture. Buzan i Vejver su zbog toga predstavili dva prelazna stanja: pre-kompleks (eng. pre-complex) i proto-kompleks (eng. proto-complex). Videti više u: Buzan and Wæver 2003, 64.
} 
pretpostavku da se međunarodni odnosi zasnivaju na anarhiji. Isto se može reći i za svaki RBK pojedinačno, s tim da Evropski RBK ima određeni stepen hijerarhije, ali je još uvek daleko od toga da postane idealni hijerarhijski sistem. Sledeći element esencijalne strukture kompleksa je polaritet koji se odnosi na raspodelu moći među jedinicama RBK. Tako kompleks može biti unipolaran (npr. Južna Afrika), bipolaran (npr. Južna Azija) ili multipolaran (npr. Srednji Istok ili Južna Amerika). Poslednji deo strukture je socijalna konstruisanost kompleksa koja pokriva obrasce prijateljstva i neprijateljstva između jedinica. Mapiranjem ovih elemenata kroje se RBK, a njihovim praćenjem se i predviđaju promene koje dovode do evolucije kompleksa. Tako ovaj pristup omogućuje da se regionalna bezbednost analizira kako u statičkom tako i u dinamičkom smislu.

Promenom nekog od elemenata strukture dolazi do transformacije kompleksa. Buzan i Vejver predviđaju tri moguće transformacije (Buzan and Wæver 2003, 53). Prva je održavanje status quo-a, koji podrazumeva da postoje promene, ali ne u meri koja bi narušila esencijalnu strukturu RBK. Druga je unutrašnja transformacija pri kojoj se granice kompleksa ne menjaju, ali dolazi do promena ili anarhične strukture (zbog regionalnih integracija, i u tom slučaju iz anarhije u hijerarhiju), polariteta (zbog dezintegracije, integracije, osvajanja, različite stope rasta, odnosno na bilo koji način kada neka nova država stekne toliku vojnu moć da izazove promenu odnosa snaga), ili dominantnog modela prijateljstva i neprijateljstva (zbog ideoloških promena, iznurenosti od rata, promene lidera itd.). Treća je spoljašnja transformacija, koja podrazumeva da se spoljašnja granica proširuje ili sažima promenom članstva regionalnog bezbednosnog kompleksa.

\section{Potkompleksi}

Buzan i Vejver predvideli su i postojanje bezbednosnih potkompleksa. Potkompleks ima u suštini istu definiciju kao kompleks, s razlikom da je čvrsto ugrađen unutar većeg RBK. Potkompleksi predstavljaju karakteristične modele bezbednosne međuzavisnosti koji su, i pored toga, obuhvaćeni širim modelom koji definiše RBK u celini (Buzan and Wæver 2003, 51). Aparatura potkompleksa eliminiše najveći deo onoga što bi inače moglo da dovede do, za TRBK, uznemirujućih slučajeva preklapajućeg članstva između RBK-a (Buzan and Wæver 2003, 52). Potkompleks ima jasne granice unutar kojih je većina bezbednosnih interakcija orijentisana 
ka unutra, tj. bezbednosna međuzavisnost je intenzivnija unutar nego izvan njegovih granica.

Potkompleksi mogu imati različite uloge (mesto) u kompleksu. Mogu biti periferija, dok su druge jedinice jezgro, što je najčešće slučaj u centriranim kompleksima i onima sa jednim potkompleksom, kao što je Evropski. Druga mogućnost je da potkompleksi budu glavni akteri kompleksa, te u tom slučaju oni „,služe kao markeri za moguće razdvajanje, ukoliko nestanu dominantna pitanja koja drže potkomplekse uvezanim" (Buzan and Wæver 2003, 66).

Očite primere potkompleksa možemo naći na Srednjem istoku, gde se kao posebni potkompleksi izdvajaju Levant (Egipat, Izrael, Jordan, Sirija i Liban) i Zaliv (Iran, Irak i zemlje Saveta za saradnju arapskih država Persijskog zaliva - Saudijska Arabija, Bahrein, Kuvajt, Ujedinjeni Arapski Emirati, Katar i Oman), koji su toliko isprepletani i međuzavisni da ne mogu biti nezavisno posmatrani (sve zalivske države su neprijatelji Izraelu, rivalstvo između Sirije i Iraka itd.) (Buzan and Wæver 2003, 51-52). U ovom slučaju dva potkompleksa (Levant i Zaliv) zajedno konstituišu Bliskoistočni kompleks kao takav, dok im je treći potkompleks (Magreb) pripojen. Nasuprot tome, primeri Zapadnog Balkana i nekih drugih potkompleksa (npr. Kavkaz) su drugačiji jer su periferni i podređeni drugoj grupi aktera koji čine jezgro RBK. Treba ovde dodati i da potkompleksi nisu neophodna karakteristika kompleksa, ali se relativno često javljaju tamo gde je broj država u regionalnom kompleksu veliki.

Bili potkompleksi u centru RKB ili na njegovoj periferiji, oni su po svojoj prirodi ugrađeni u kompleks. Niti se bezbednosna dinamika potkompleksa može u potpunosti shvatiti ako se ne uzmu u obzir interakcije sa ostatkom kompleksa, niti se kompleks može razumeti bez potkompleksa kao svog integralnog dela.

Promenom bezbednosne dinamike može doći do transformacije kako potkompleksa, tako i kompleksa. Kako je teritorijalnost jedan od stožera teorije regionalnog bezbednosnog kompleksa, geografski položaj potkompleksa unutar kompleksa važan je u slučaju transformacije. Potkompleksi koji su zaključani u kompleks, odnosno okruženi jedinicama koje čine kompleks, svojom dezintegracijom ne mogu uticati na promenu spoljašnjih granica

\footnotetext{
${ }^{7}$ Pod uslovom da ta spoljašnja granica nije ka moru/okeanu, tj. nije granična ka susednom kompleksu.
} 
kompleksa. Primer za to je odnos Zapadnobalkanskog potkompleksa i Evropskog kompleksa. Slučajevi kada su potkompleksi na rubu kompleksa, tj. čine jednu od spoljašnjih granica kompleksa, ${ }^{7}$ su značajniji jer takvi potkompleksi mogu izazvati ne samo transformacije svog matičnog kompleksa već i susednog, ako dođe do intenziviranja bezbednosne dinamike.

\section{Tipovi kompleksa}

Unutar ovih parametara strukture i evolucije moguće je uočiti različite tipove regiona, smatraju Beri Buzan i Ule Vejver, te razlikuju komplekse po formi i polaritetu, u zavisnosti od toga da li se kao glavni kriterijum uzimaju modeli prijateljstva i neprijateljstva ili raspodela moći u RBK, odnosno broj značajnih sila. Što se tiče tipologije po polaritetu, manje važne za ovaj rad, valja samo istaći da treba razlikovati standardni i centrirani RBK, te da postoji mogućnost nastajanja RBK „velikih sila“ i eventualne pojave superkompleksa. ${ }^{8}$

Podela po formi je socijalno-konstruktivistička jer se odnosi na obrasce prijateljstva i neprijateljstva i zasniva na tome na kom se delu spektra nalaze unutrašnje dinamike bezbednosnog kompleksa - na negativnom kraju smeštene su konfliktne formacije, u sredini su bezbednosni režimi, dok se na pozitivnom kraju spektra nalaze bezbednosne zajednice.

U konfliktnoj formaciji, međuzavisnost proizilazi iz straha, rivalstva i percepcije jednih drugih kao pretnji. Finski teoretičar Raimo Vajrinen ovakvo stanje naziva regionalnom konfliktnom formacijom, definišući je kao „složenu mešavinu intra-nacionalnih, intra-regionalnih i ekstraregionalnih konflikata nasilnog karaktera" (1984, 344). Govoreći o karakteristikama ovih konfliktnih formacija, Vajrinen kaže da su one uglavnom složene i zamršene $u$ tom obimu da ne mogu biti lako dekomponovane na pojedinačne konflikte. Odnosi u ovakvom kompleksu obeleženi su hobsovskom anarhijom, ratu svih protiv svih.

Ako se konfliktna formacija najbolje vezuje sa Hobsa, onda bezbednosni režim upućuje na Džona Loka. Suština ovog tipa odnosa u kompleksu je

\footnotetext{
${ }^{8}$ Više o tipovima kompleksa u odnosu na polaritet videti u: Buzan and Wæver 2003, 55-61. Treći oblik centriranog RBK je posebno interesantan jer podrazumeva region koji je integrisan pre institucijama nego nekom silom. ERBK predstavlja jedinstven primer ove forme kompleksa jer je integrisan Evropskom unijom.
} 
da države i dalje tretiraju jedna drugu kao potencijalnu pretnju, ali prave osiguravajuće aranžmane kako bi smanjile bezbednosnu dilemu. Rečima Roberta Džervisa (Robert Jervis) (1982), bezbednosni režimi nastaju kada "grupa država sarađuje u upravljanju spornim pitanjima sa ciljem izbegavanja rata, nastojeći da smanje bezbednosnu dilemu tako što uz istovremeno samostalno delovanje uzimaju u obzir i ponašanje drugih“. Džervis je popisao i uslove potrebne za nastanak i opstanak režima. Prvi je da velike sile žele njegovo uspostavljanje, odnosno da akteri moraju verovati da drugi dele vrednosti o zajedničkoj bezbednosti i saradnji (drugi uslov). Treći i ključni uslov je da svi glavni akteri moraju biti zadovoljni sa status quo-om. Drugim rečima, bezbednosni režim se ne može formirati kada jedan ili više aktera veruje da je bezbednost najbolje ostvarena i obezbeđena ekspanzijom.

Na pozitivnom kraju spektra modela prijateljstva i neprijateljstva nalazi se bezbednosna zajednica, oblik trajne i stabilne miroljubive saradnje u kojoj je prevaziđeno ponašanje $u$ obrascu bezbednosne dileme. Sjedinjene Američke Države i Kanada, nordijske zemlje i Evropska unija karakteristični su primeri bezbednosnih zajednica, termina koji se vezuje se Karla Dojča (Karl Deutsch). Dojč razlikuje pluralističku i amalgamiranu bezbednosnu zajednicu. Amalgamirana je ona u kojoj više država udružuje putem stvaranja zajedničkih ustanova, s tim da je Dojč pod njom podrazumevao $\mathrm{i}$ "svaku razumnu, dobro integrisanu nacionalnu državu“ (1957). U odnosu na ovu, pluralistička bezbednosna zajednica predstavlja labaviji oblik odnosa jer podrazumeva stanje odnosa između neamalgamiranih država, ali čiji se vrednosni sistemi međusobno ne isključuju, a zajednički identitet im omogućava visok nivo veza i saradnje, razmene mišljenja i bliskosti u odnosima. Drugim rečima, političke razlike između država članica pluralističke bezbednosne zajednice su dopuštene, ali se postojanjem mogućnosti uvida u proces donošenja odluka kod druge ili ostalih država članica, kao i putem postupaka tzv. uhodane razmene mišljenja može delotvorno preduprediti da pojedine razlike ne prerastu $u$ nasilne sukobe (Simić 2002, 46-47).

\section{INSULATOR U TRBK}

Kako je već istaknuto, insulator je originalni koncept koji su u studije bezbednosti uveli Buzan i Vejver. Njegova intelektualna istorija svakako 
ima veze sa starijim i češće korišćenim konceptom tampon država (engl. buffer state). Ipak, postoji suštinska razlika između ova dva pojma. Tampon država se nalazi u centru snažne sekuritizacije, za razliku od insulatora koji se nalazi na njenoj granici (Buzan and Wæver 2003, 41). Tampon država se nalazi unutar RBK i razdvaja glavne aktere $u$ regionu, dok je insulator pozicioniran između različitih RBK te razdvaja njihove bezbednosne dinamike (Buzan and Wæver 2003, 483).

Buzan je u svojoj studiji People, States and Fear kao klasične primere insulatora naveo Mjanmar (Burmu) između Južne i Jugoistočne Azije tokom Hladnog rata, Tursku između Evrope, Bliskog istoka i Postsovjetskog kompleksa, Avganistan između Južne Azije i Bliskog istoka i Nepal između Južne i Severoistočne Azije. Buzan je predvideo i da insulator ne mora biti samo individualna država već i grupa država, pa je tako i pojasu država koje se prostiru od Mauritanije do Sudana dodelio status insulatora $(1991,196)$. Popunjavajući mapu sveta, Buzan i Vejver su uvideli da je potrebno dodati još jedan oblik insulatora - minikompleks. Minikompleks postaje insulator u situaciji kada susedi razvijaju bezbednosnu dinamiku sa graničnim delom/državom minikompleksa, ali se ta dinamika ne proširuje na ostatak minikompleksa, niti na regionalni bezbednosni kompleks koji se nalazi s druge strane minikompleksa. Primer minikompleksa je Avganistan, $\mathrm{u}$ trenutku kad je zbog stanja na terenu više funkcionisao kao prostor, nego kao teritorija suverene države.

Buzan i Vejver u svojoj zajedničkoj studiji naglašavaju da je insulator tradicionalno pasivan igrač koji „apsorbuje“ energiju iz razdvojenih kompleksa. Oni navode da Turska odudara od ovog opšteg modela jer predstavlja aktera koji itekako emituje energiju u okolne komplekse.

Usled postojanja različitih oblika insulatora - države, grupe država, minikompleksa - čini se analitički i prediktivno korisnim uvođenje i kategorizacija insulatora $\mathrm{u}$ odnosu na to kakvu oni ulogu imaju $\mathrm{u}$ bezbednosnoj dinamici geopolitičkog prostora u kojem deluju. Stoga se predlaže inovacija teorije regionalnog bezbednosnog kompleksa uvođenjem bližih određenja - pasivni i aktivni insulator. Pasivni insulator u ovakvoj podeli predstavljao bi tradicionalnog, odnosno uobičajenog insulatora koji razdvaja bezbednosne dinamike okolnih kompleksa, apsorbujući njihove energije. Dakle, imao bi klasičnu ulogu izolatora. Za razliku od njega, aktivni insulator bio bi onaj koji više emituje energiju, ali ne u dovoljnoj meri da ujedini različite komplekse $\mathrm{u}$ jedan jedinstveni. Kako se na bezbednosnoj dinamici, odnosno interakciji između jedinica, temelji teorija regionalnog 
bezbednosnog kompleksa, ovi insulatorski akteri bi se mogli nazvati i insulatori akcije (aktivni), odnosno insulatori reakcije (pasivni).

Razlog više za uvođenje ovakve dihotomije insulatora je i što bi etiketiranje insulatora jasnije ukazivalo na kakvoću bezbednosne dinamike u regionu i sugerisalo prirodu moguće transformaciju kompleksa.

U nastavku se ova dihotomija primenjuje na konkretne slučajeve insulatora. Najviše pažnje je posvećeno Turskoj kao posebno kompleksnom primeru insulatora. Nakon toga se i ostali insulatori raspoređuju po novom, binarnom ključu.

\section{Turska u TRBK}

Turska je insulator između tri kompleksa - Evropskog, Bliskoistočnog i Postsovjetskog jer nosi teret svoje teške pozicije, ali i zbog toga što nije dovoljno snažna da ujedini ove svetove $u$ jedan jedinstveni (Buzan and Wæver 2003, 41).

Turska je očiti primer aktivnog insulatora, odnosno insulatora akcije jer svojim delovanjem pokušava da utiče na sva tri kompleksa sa kojima je u interakciji. Ona je dinamičan akter i važan činilac u unutrašnjim dinamikama tih kompleksa, ali i činilac u njihovim interakcijama sa spoljašnjim svetom. Kao takva, izazivala je pažnju istraživača više nego drugi primeri insulatora u TRBK (Barrinha 2014; Diez 2013).

Treba naglasiti da Turska negira da je insulator. Buzan i Vejver ističu da kako „termin insulatora nije još u široj upotrebi, Turska više negira da je tampon država, jer je to poznatiji, klasičniji, geopolitički termin kojeg su turski donosioci odluka svesniji (i kojeg se boje). Iako turski političari ne negiraju ovu ulogu pozivajući se na TRBK, jasno je da ne vide ni ulogu tampona niti insulatora kao atraktivnu“ (Buzan and Wæver 2003, 41).

Turska učestvuje $\mathrm{u}$ bezbednosnim dinamikama sva tri okolna kompleksa, s tim da ih istovremeno i razdvaja i spaja u odnosu na to koji se aspekt bezbednosne dinamike posmatra, tj. koji se konkretni kompleks analizira. Ono što analizu statusa Turske u TRBK dodatno usložnjava je to što ona održava izuzetno aktivne odnose sa potkompleksima unutar susednih kompleksa.

Istorijski posmatrano, tokom dugog perioda postojanja Osmanskog carstva, Turska je de facto činila Bliskoistočni (pot)kompleks, što se promenilo nakon Prvog svetskog rata i stvaranja sekularne države 
zapadnog modela pod vizijom Kemala Ataturka. Od dolaska na vlast Partije pravde i razvoja (AKP), Turska vodi izuzetno dinamičnu spoljnu politiku s ambicijom da bude globalno relevantan igrač. Iako i dalje usmerena ka tom cilju, događaji u bliskom okruženju otežavaju Turskoj da dostigne globalni domet jer je preokupirana regionalnim izazovima. Upravo ta geopolitička fragilnost njene pozicije je lako može dovesti do rasutosti jer istovremeno mora da bude involvirana u različite bezbednosne dinamike, a da pritom nijednu sasvim ne kontroliše (Barrinha 2014, 180). Time ugrožava i svoju dugoročnu globalnu strategiju jer u stalnom riziku od "opasne preraširenosti“" (Abramowitz and Barkey 2009, 127).

$\mathrm{U}$ posthladnoratovskom periodu, $\mathrm{u}$ odnosu prema Bliskoistočnom potkompleksu, Turska je tradicionalno održavala bliske vojne odnose sa Izraelom i igrala je značajnu ulogu u bliskoistočnom mirovnom procesu (Muftuler-Bac 2000). Situacija se bitno promenila nakon incidenta 2010. godine kada se izraelska mornarica sukobila sa turskim konvojem humanitarne pomoći. Turska je povukla ambasadora iz Tel Aviva i zatražila hitnu sednicu Saveta bezbednosti UN. Odnosi su toliko bili zategnuti da je, prema nekim izvorima, Turska u svom petogodišnjem dokumentu koji definiše tursku bezbednosnu politiku, poznatom kao "Crvena knjiga“, po prvi put označila Izrael kao „veliku pretnju“ (eng. major threat) (Panarmenian 2010; The Jerusalem Post 2010). Uprkos pokušaju otopljavanja 2016. godine (Kanat and Hannon 2017), odnosi između Izraela i Turske su se ponovo naglo pogoršali 2018. godine nakon nasilnih protesta u pojasu Gaze kada je poginulo preko 60 Palestinaca, za čiju smrt je Turska direktno optužila Izrael nazivajući ga "terorističkom državom“ (Staff 2020). Turska je tada povukla svog ambasadora iz Izraela i proterala izraelskog ambasadora u Ankari i konzula u Istanbulu. Iako je bilo više najava krajem 2020. godine i početkom 2021. godine da će na inicijativu Turske doći do vraćanja diplomatskih odnosa na nivo ambasadora, to se do sada nije dogodilo. Izrael je $\mathrm{u}$ međuvremenu ojačao svoj položaj u regionu, naročito u Mediteranu, gde je 2020. godine sklopio strateški ugovor sa Kiprom i Grčkom o podvodnom gasovodu (Ulusoy 2020) koji je naišao na snažne otpore Turske, koja tvrdi da isti delom prolazi kroz njene teritorijalne vode. Ovaj projekat je samo pojačao već postojeće tenzije između Turske i Kipra, odnosno Turske i Grčke oko istraživanja energetskih izvora u Mediteranskom moru.

Druga arena u Bliskoistočnom kompleksu od ogromnog značaja za Tursku je Sirija. Zbog sukoba u Siriji, Turska je ušla u vrlo komplikovane odnose sa glavnim svetskim igračima - SAD i Rusijom. Početak sukoba 
2011. godine izazvao je pogoršanje odnosa Turske i Rusije čiji su interesi u Siriji bili direktno suprotstavljeni jer je Rusija podržavala Asadov režim, a Turska aktivno pomagala pobunjenike. Vrhunac krize u odnosima dogodio se nakon obaranja ruskog lovca bombardera Su-24 od strane turskih oružanih snaga novembra 2015. godine. Ipak, mirovni pregovori u Astani krajem 2016. i početkom 2017. godine oko rešavanja sirijske krize doprineli su poboljšanju odnosa. Zajedničko nadgledanje prekida vatre i turske vojne operacije u tursko-sirijskom pograničnom pojasu sprovedene uz saglasnost Moskve dale su vetar u leđa bilateralnim odnosima, koji su nastavili da jačaju. Avgusta 2018. godine, Sergej Lavrov je u govoru turskim ambasadorima u Ankari govorio o "unapređenju strateškog partnerstva“ između dve države, dok je u uzvratnoj poseti turski ministar spoljnih poslova Mevlut Čavušoglu govorio o Rusiji kao "turskom strateškom partneru" (Yinglun 2018). Konačno, dogovor o kupovini protivvazdušnog sistema S-400 označio je vrhunac bilateralnih odnosa, kao i sledstveno pogoršanje turskih odnosa sa NATO saveznicima, pre svega SAD koje su Turskoj uvele i sankcije zbog kupovine tog raketnog sistema. U prvim kontaktima nove američke administracije sa Turskom, Ankara je bila eksplicitna da neće odustati od kupovine ovog sistema (AlJazeera 2021). Iako je jasan trend značajnog unapređenja odnosa Moskve i Ankare, teško da će njihovi odnosi zaista dostići nivo strateškog partnerstva jer se i dalje njihovi interesi u Siriji, ali i u drugim arenama umnogome razlikuju (Köstem 2020).

Još jedan zaokret $\mathrm{u}$ turskom pristupu sirijskom sukobu izazvao je udaljavanje od zapadnih partnera. Reč je o promeni fokusa Turske sa pomoći pobunjeničkoj strani u Siriji na onemogućavanje širenja teritorije pod kontrolom Kurda, zbog kojeg je Turska sprovela nabrojane vojne operacije na teritoriji Sirije kako bi sprečila jačanje i sjedinjavanje kurdskih snaga.

Pored jasne bezbednosne dinamike na liniji Ankara-Moskva, koja se u Bliskoistočnom kompleksu transformisala iz obrasca neprijateljstva $\mathrm{u}$ obrazac prijateljstva, Turska je naročito aktivna u dva potkompleksa šireg Postsovjetskog kompleksa: Kavkaskom i Centralnoazijskom. Kavkaski potkompleks se, prema Buzanu i Vejveru, sastoji iz severnog i južnog dela. Severni čine zapravo ruske republike Čečenija, Dagestan i pet drugih jedinica, a za ovaj rad interesantniji južni deo čine Jermenija, Azerbejdžan i Gruzija, kao i sporne teritorije Nagorno Karabah, Abhazija i Južna Osetija (Buzan and Wæver 2003, 419).

Turska u ova dva potkompleksa, prema Ejdusu, ima dva važna zaloga. „Prvi predstavljaju turkofone etničke i jezičke zajednice koje tu žive i koje 
broje preko 150 miliona pripadnika, dok je drugi to što je ovaj region prirodno bogat naftom i gasom" (Ejdus 2006). Ovde je od skorašnjih događaja koji su mogli da promene regionalnu bezbednosnu konstelaciju naročito interesantno tursko akterstvo $u$ azerbejdžansko-jermenskom sukobu oko Nagorno Karabaha 2020. godine. Naime, Turska se otvoreno svrstala uz Azerbejdžan, pružajući joj vojno-političku podršku. Pored stavljanja na raspolaganje svojih vojnih stratega, Turska je optužena i da je posredovala u dovođenju stranih boraca, što joj je otvoreno zamerio predsednik Francuske Emanuel Makron (Irish and Rose 2020). Ankara je negirala ove navode. Evropski parlament je takođe upozorio na „naročito destabilizijuću ulogu i mešanje Turske“ (EP 2021). Azerbejdžan je na kraju sukoba okončanog uz posredovanje Moskve izašao kao jasan pobednik, na zadovoljstvo Turske. Stiče se utisak da je Jermenija očekivala snažniju podršku ne samo Rusije, već i Zapada, koja je gotovo u potpunosti izostala. Ruski mirotvorci su raspoređeni između Jermenije i Nagorno Karabaha kako bi obezbedili sprovođenje odredaba mirovnog sporazuma.

Konačno, teorija regionalnog bezbednosnog kompleksa prepoznaje Tursku kao insulatora i u odnosu na Evropski regionalni bezbednosni kompleks i njemu pripadajući Zapadnobalkanski potkompleks. Kao metafora koja je najbolje ilustrovala tursku ulogu prema Evropskom kompleksu može se istaći ona Olija Rena o Turskoj kao mostu između civilizacija. Može se dodati i - mosta između bezbednosnih dinamika. Turska zasigurno neće $\mathrm{u}$ dogledno vreme postati punopravna članica Evropske unije. Turska je status kandidata stekla još davne 1987. godine, otvorila je pregovore 2005. godine s tim da nijedno poglavlje ne može biti privremeno zatvoreno, a osam poglavlja ni otvoreno zbog odbijanja Turske da primeni Dodatni protokol koji se odnosi na Kipar. Usled dugotrajno narušenih odnosa sa EU i jačanja autokratskih tendencija, Evropska unija je 2018. godine zamrzla pregovore sa Turskom.

Turska, međutim, ostaje važan činilac za Evropsku uniju, ne samo ekonomski već i bezbednosno, jer Turska nakon izbijanja sirijske izbegličke krize 2015. godine de facto kontroliše priliv izbeglica u Evropsku uniju. Pored toga, bilateralni odnosi Turske sa najvažnijim članicama EU takođe su važan faktor u dinamici odnosa na EU nivou.

Nakon izbora na nivou EU, nova garnitura lidera učinila je korake ka otopljavanju odnosa sa Turskom. Sa najviših instanci Evropske komisije i Evropskog saveta stizale su oprezne, ali optimistične poruke da je došlo vreme za obnavljanje bliže saradnje. Ipak, ove poruke su praćene i 
isticanjem brojnih problema koji i dalje tište odnose dve strane, poput sporova $\mathrm{u}$ istočnom Mediteranu, pitanja Kipra, različitih interesa $\mathrm{u}$ sukobima u Libiji i Siriji, kao i snižavanje demokratskih standarda u Turskoj (EEAS 2021).

Poseta predsednika Evropskog saveta, Šarla Mišela, i predsednice Evropske komisije, Ursule fon der Lajen, Ankari u aprilu 2021. godine, umesto da posluži kao dokaz tog otopljavanja nakon vrlo turbulentne 2020. godine, ostala je zapamćena po tzv. "sofagate“-u (BBC 2021). Do njega je došlo zbog protokolarnog propusta nakon kojeg je for der Lajen, umesto da sedi u ravni sa Mišelom i Erdoganom, smeštena na sofu pored. Obe strane su kasnije svaljivale krivicu na protokole druge strane. Kako god da je došlo do njega, ovaj propust je dobio daleko više na publicitetu jer je poslužio kao paradigma odnosa Turske prema ljudskim pravima i rodnoj ravnopravnosti. Ovaj incident je, takođe, koincidirao sa Erdoganovim predsedničkim dekretom kojim je pokrenuto povlačenje Turske iz Konvencije Saveta Evrope o sprečavanju i borbi protiv nasilja nad ženama i nasilja u porodici, poznate kao Istanbulska konvencija. Ta odluka je naišla na nepodeljenu osudu međunarodne zajednice, uključujući sve glavne stručne mehanizme za ljudska prava Ujedinjenih nacija i Saveta Evrope, jer će se time drastično umanjiti zaštita prava žena i to u trenutku kada je povećan broj slučajeva porodičnog nasilja i femicida u Turskoj. Zaista, razvoj događaja ukazuje da je cilj Ankare da svoj odnos sa EU limitira na pitanja trgovine, ekonomije i upravljanje migracijama (Pierini 2021). Ostaje da se vidi kako će EU odgovoriti na to, odnosno da li će uspeti da se dogovori oko zajedničke strategije prema Turskoj $\mathrm{u}$ fazi kada ona očigledno ne deli vrednosti na kojima Evropska unija počiva, a na šta ukazuje sve manji prostor za delovanje civilnog društva, kritički nastrojene akademske zajednice i branilaca ljudskih prava.

Kada se sagleda ukupnost odnosa EU i Turske, čini se opravdanim reći da će Turskoj i narednih decenija pozicija insulatora biti limit u odnosu na Evropski kompleks, bez izglednijih mogućnosti da bude apsorbovana. Opet, sve dok članstvo u EU bude glavni, pa makar i samo deklarativni, strateški cilj Turske, za očekivati je da uloga insulatora neće ni derogirati. To pod uslovom da se razvoj događaja na Bliskom istoku, na kojem Turska nesporno podiže nivo bezbednosne dinamike sve manje šireći obrasce prijateljstva a sve češće neprijateljstva (Izrael, Sirija), toliko ne intenzivira da dovede do toga da se ona u potpunosti zakopča u svoj bliskoistočni šinjel, postajući time jedinica tog kompleksa i gubeći status insulatora 
prema Evropskom i Postsovjetskom kompleksu. Ipak, ovo ostaje nerealno zbog turskih ambicija da bude globalno relevantni akter. Ukoliko želi da projektuje svoju moć, Turska ne može sebi da dozvoli da zaključa svoju orijentaciju samo prema jednoj interesnoj zoni.

O akterstvu Turske na Zapadnom Balkanu je dosta pisano proteklih godina (Tanasković 2010; Glodić 2011; Pavlović 2016; Tanasković 2021), uključujući i u kontekstu TRBK (Milenković 2020), te se ovde neće ulaziti u podrobniju eksplikaciju. Turska se poslednjih godina nametnula kao neizostavan činilac bezbednosne dinamike na Zapadnom Balkanu. Njeno delovanje $u$ regionu najčešće je analizirano kroz koncept neoosmanizma. Pod ovim pojmom Darko Tanasković podrazumeva „kompleksnu makroideološku platformu prema kojoj današnja Turska, kao njegova legitimna civilizacijska naslednica, treba da reafirmiše celokupno duhovno, kulturno i političko nasleđe Osmanskog carstva, kako bi u preraspodeli svetske moći i uticaja, koja je u toku, obezbedila i delotvorno igrala ulogu jednog od globalno značajnih međunarodnih činilaca" $(2010,8)$. Omer Tašpinar (Ömer Taspinar), profesor na Ratnom koledžu SAD i direktor Turskog programa na Brukings institutu, ističe da „neoosmanizam prihvata veliku, geostratešku viziju Turske kao efektnog $\mathrm{i}$ angažovanog regionalnog faktora koji pokušava da reši regionalne i globalne probleme“ $(2008,3)$.

Svojom neoosmanskom politikom, Turska naglašava da je Zapadni Balkan deo njenog "nacionalnog bića“ i važan deo u mozaiku postavljanja osnove za Tursku kao globalnog aktera. Turska želi da bude lider regionalnih političko-bezbednosnih inicijativa i pokretač je glavnih trilateralnih mehanizama u Zapadnobalkanskom potkompleksu. Mireći političare i verske lidere na ovom prostoru, značajno uvećavajući svoje investicije u region i povećavajući svoje kulturno prisustvo, projektuje svoju meku moć gradeći sebi poziciju regionalnog lidera.

Spoljna politika Turske dolaskom AKP početkom 2000-ih u velikoj meri je građena na viziji Ahmeta Davutoglua, koji je od savetnika predsednika (Erdogana) za međunarodne odnose, preko ministra spoljnih poslova i predsednika Vlade ispred AKP, stigao do statusa opozicionog političara, kada se nakon sukoba sa Erdoganom 2019. godine povukao iz članstva u AKP i osnovao svoju Partiju budućnosti. Ipak, njegov pogled na region i dalje je vrlo vidljiv u turskom delovanju prema Balkanu:

„Sa stanovišta turskih interesa u klizavim i promenjivim regionalnim odnosima na Balkanu, nepromenjivi i najvažniji strategijski prioriteti 
su elementi stabilnosti i bezbednosti, kao i problem opstanka u svojim oblastima i garancije zajednicama koje su zaostavština Osmanskog carstva i koje sigurnost svoje sudbine vide samo kroz tursku moć i uticaj u regionu. Ova situacija za Tursku nije samo odgovornost i teret, već ujedno predstavlja i najvažnije sredstvo za formiranje turske sfere uticaja na Balkanu" (Marković 2011, 211). ${ }^{9}$

Upravo ovaj stav predstavlja dokaz turske neoosmanističke politike na Zapadnom Balkanu, ali i njenih daljih intencija. Stoga je za očekivati da Turska nastavi sa trenutnom politikom na Balkanu jer zbog istorijskih, kulturnih, demografskih, geografskih, ekonomskih i političkih veza, ovaj region prirodno predstavlja tursku arenu. Što se tiče njenog akterstva prema Zapadnobalkanskom potkompleksu sa stanovišta teorije regionalnog bezbednosnog kompleksa, iako vanredno dinamično, ono ostaje $\mathrm{u}$ domenu insulatora. $\mathrm{U}$ tom smislu, etiketiranje Turske kao aktivnog insulatora, odnosno insulatora akcije, dodatno dobija na smislu kada se sagledava iz perspektive njenih odnosa sa potkompleksima komšijskih kompleksa.

\section{Ostali insulatori}

Kako bi se proverila održivost koncepta aktivni/pasivni insulator, treba ga primeniti na ostale države insulatore $u$ TRBK. Zbog ograničenog obima rada, ovde se nakon propitivanja centralnog primera Turske nudi inicijalno skiciranje primene insulatorske dihotomije na druge države koje imaju isti status $\mathrm{u}$ TRBK, s tim da je $\mathrm{u}$ perspektivi uputno sprovesti opsežnije pojedinačne studije slučaja kako bi se temeljnije istražilo insulatorsko akterstvo ovih država. Ukratko će se sagledati primeri Mjanmara, Nepala, Avganistana, Mongolije i Ukrajine.

Mjanmar je tradicionalno predstavljao primer države koja obitava u relativnoj izolaciji od bezbednosnih dinamika sa spoljašnjim svetom (Buzan and Wæver 2003, 486). Od sticanja nezavisnosti 1948. godine, Mjanmar je uglavnom bio pod vojnim režimom koji je vladao od 1962. do 2011. godine kada je konačno vlast preneta civilnim organima. Tokom perioda vojne vlasti, što zbog sankcija koje mu je nametnula međunarodna zajednica, što

\footnotetext{
${ }^{9}$ Ovde namerno navodimo prevod originalnog turskog izdanja u prevodu Miloša B. Markovića, a ne srpski prevod, koji je autor upodobio regionalnoj publici.
} 
zbog opredeljenja vojnog režima da se fokusira na probleme unutar države, Mjanmar je zaista bio pasivni insulator.

Situacija počinje da se menja oslobađanjem iz višegodišnjeg nezakonitog pritvora Aung San Su Ći (Aung San Suu Kyi), borkinje za ljudska prava i dobitnice Nobelove nagrade za mir 1991. godine. Dok je na prvim, samo formalno demokratskim izborima 2011. godine pobedu odnela partija pod de facto kontrolom vojnog vrha, na prvim zaista slobodnim izborima 2015. godine, partija Nacionalna liga za demokratiju pod vođstvom Aung San Su Ći odnosi ubedljivu pobedu. Takav razvoj je bio konsenzusno pozdravljen od strane međunarodne zajednice. SAD i EU su opredelile značajna finansijska sredstava za razvojnu pomoć. Činilo se da je Mjanmar na putu da napusti svoju izolacionističku politiku. Uspešno je balansirao između saradnje sa Indijom i Kinom na infrastrukturnim projektima, ne želeći da dâ jasan primat nikome. Iz ugla bezbednosnih odnosa sa okolnim državama, Mjanmar je uglavnom bio izvoznik problema ${ }^{10} \mathrm{zbog}$ brojnih etničkih manjina koje već decenijama zagovaraju svoju nezavisnost. Problem militantnih grupa u pograničnom pojasu je naročito izražen na granici sa Indijom (Basit 2018) gde su dve države neretko sarađivale na njihovom gušenju.

Režim Aung San Su Ći počeo je da gubi međunarodnu podršku zbog vojnih operacija koje su naterale više stotina hiljada pripadnike etničke manjine Rohindža (Rohingya) da napuste državu, uputivši se uglavnom prema Bangladešu. Ujedinjene nacije su oštro osudile ovu akciju, Visoki komesar UN za ljudska prava ju je nazvao udžbeničkim primerom etničkog čišćenja (UN News 2018), dok se slučajem bavio i Međunarodni sud pravde koji je 2020. godine, po tužbi Gambije ispred Organizacije islamske saradnje, doneo obavezujuće privremene mere kako bi se sprečio genocid i onemogućilo uništavanje dokaza (UN News 2020). Aung San Su Ci je i sama svedočila pred Sudom 2019. godine negirajući genocidnu nameru, naglašavajući da činjenično stanje nije adekvatno predstavljeno i ističući da će svi odgovorni biti izvedeni pred domaći sud ukoliko postoje dokazi o njihovima zlodelima.

Zbog egzodusa Rohindža, Mjanmar je ponovo suočen sa međunarodnim sankcijama i umnogome opet izolovan. Ovu situaciju je iskoristilo vojno vođstvo koje je izvršilo vojni udar 2021. godine, ubrzo

${ }^{10}$ Više o bezbednosnoj situaciji u Mjanmaru videti u: Rainer and Goel 2020. 
nakon parlamentarnih izbora na kojima je ponovo pobedila stranka Aung San Su Ći. Ona je, kao i većina dotadašnjeg državnog vrha, pritvorena, dok je u demonstracijama koje su usledile ubijeno više stotina ljudi. Vojni udar je izazvao nepodeljenu reakciju Zapada. SAD, UK i EU nametnule su sankcije vojnim liderima. Savet bezbednosti UN je, doduše nakon teških pregovora, uspeo da se složi oko zajedničke izjave kojom osuđuje nasilje u Mjanmaru. Mjanmar odbija da primi međunarodne posmatrače, uključujući i one iz ASEAN-a (Reuters 2021), iako je vojno rukovodstvo uspostavilo bilateralne kontakte sa pojedinim okolnim državama. Ostaje da se vidi kako će se situacija razvijati, ali ukoliko vojna vlast opstane duže na vlasti za očekivati je da Mjanmar opet utone u samoizolaciju i nastavi da dela kao pasivni insulator na svoje susede.

Nepal se takođe karakteriše kao insulator, ukoliko i dalje mogu razlikovati Južna Azija i Severoistočna Azija kao dva zasebna kompleksa. Čak i ukoliko Azija postane jedan kompleks, nepalska uloga klasičnog izolatora bi posebno došla do izražaja te ga takođe možemo svrstati $u$ pasivne insulatore. Nepal je ne samo geografski pozicioniran kao insulator već i ekonomski i političko-bezbednosno. Kompletno okružen Indijom i Kinom, položaj Nepala sa stanovišta TRBK će se teško promeniti. Nepal je logistički veoma zavistan od Indije, jer gotovo sva trgovinska razmena Nepala tranzitira preko Indije. Odnosi između dve države narušeni su od usvajanja ustavnih amandmana u Nepalu, kojima se Indija protivila zbog graničnih sporova koje dve države imaju. Sa druge strane, jačaju odnosi Nepala sa Kinom koja je od 2015. godine lider u stranim direktnim investicijama u Nepal.

Još jedan primer države insulatora kroz istoriju, ali i danas, je Avganistan jer operiše između tri kompleksa - Južnoazijskog, Bliskoistočnog i Postsovjetskog. Avganistan je zbog specifičnog geografskog položaja, ali i društvenog uređenja, bio izrazito pasivni insulator, što se zbog sukoba vođenih od 80-ih godina XX veka pa do danas u znatnoj meri promenilo. Avganistan je od posebnog značaja za TRBK jer je teren gde su nedržavni akteri postali posebno aktivni i jedan je od razloga zbog kojeg su Buzan i Vejver morali da rediguju svoju definiciju regionalnog bezbednosnog kompleksa, uključujući nedržavne aktere, menjajući formulaciju iz "grupe država“ $u$ "set jedinica“. Zbog toga što centralna vlast ne vrši ni opštu ni efektivnu kontrolu nad nekim delovima svoje teritorije, upitno je da li se Avganistan može smatrati jedinstvenim bezbednosnim akterom. Stoga bi pre mogao biti okarakterisan kao 
„insulatorska zona“ ili minikompleks, nego insulator. Avganistan nije u tom smislu jedinstven. Koncept insulatorske zone su Buzan i Vejver koristili da označe prostor između Magreba i Zapadne Afrike koji zauzimaju Mauritanija, Mali, Niger, Čad i delimično Centralnoafrička Republika (Buzan and Wæver 2003, 258).

Iako je de jure nezavisna mnogo duže, Mongolija je de facto postala nezavisna tek nakon Hladnog rata jer je tokom istog bila pod sovjetskim prekrivačem (overlay). Tokom istorije, ali i danas, okružena je dvema velikim silama - Kinom i Rusijom, sa kojima je u različitim etapama imala i sizerenski odnos. Od 1992. godine Mongolija je insulator koji održava uravnotežen odnos sa obema silama. Bezbednosni problem, koji se najčešće javlja, prouzrokovan je neadekvatnom demarkacijom granica kako prema Kini tako i prema Rusiji. Povremeni granični incidenti koji nastaju usled kretanja nomadskog stanovništva ipak nisu dramatični. Kako Mongolija pre apsorbuje energije susednih velikih sila, usled objektivno podređenog položaja koji ima u odnosu na njih, mogla bi se označiti kao pasivni insulator.

Konačno, čini se uputnim da se ukratko razmotri današnji status Ukrajine u TRBK. U vreme pisanja knjige Regions and Powers, Ukrajina je bila deo Postsovjetskog kompleksa sa Rusijom kao velikom silom. Buzan i Vejver su još tada istakli da su baltičke države, Ukrajina i Moldavija, granični akteri između Evropskog i Postsovjetskog kompleksa te da ta granica nije konačna $(2003,374)$. Govoreći o mogućim sukobima napomenuli su da se oni ne mogu isključiti $(2003,417)$, te su ispravno prognozirali da će se to najverovatnije desiti oko Krima $(2003,418)$. Aneksija Krima, kao i sukobi na istoku Ukrajine, međutim, nisu uticali na transformaciju Postsovjetskog kompleksa jer je Ukrajina i bila njegova članica. Štaviše, sve dok sukob traje, u kakvoj god da je formi, Ukrajina će biti usisana u Postsovjetski kompleks. To bi se moglo promeniti otvorenim ulaskom članica Evropskog (EU) kompleksa u sukob, kada bi potencijalno došlo do stvaranja superkompleksa spajanjem Evropskog i Postsovjetskog kompleksa. Međutim, taj scenario se ne čini realističnim kada se sagleda dosadašnji tok sukoba, odnosno reakcija EU na aneksiju Krima. Ukoliko se pretpostavi da Krim ostaje u ruskim rukama, da će se sukobi na istoku Ukrajine okončati a da će Kijev nastaviti da vodi prozapadnu politiku, realniji je scenario da Ukrajina postane insulator između ova dva kompleksa. 


\section{ZAKLJUČAK}

$\mathrm{U}$ fokusu ovog rada bio je koncept insulatora $\mathrm{u}$ teoriji regionalnog bezbednosnog kompleksa. Ovaj koncept je uveden kako bi se prevazišla teškoća u određivanju granica između regiona, odnosno kompleksa, odnosno kako bi se objasnilo različito delovanje jedinica (pre svega država) $\mathrm{u}$ odnosu na regionalni bezbednosni kompleks kojem ne pripadaju.

Buzan i Vejver ističu da su se glavni insulatori u TRBK (poput Turske i Avganistana, prim. aut.) pokazali kao prilično trajni i konzistentni (Buzan and Wæver 2003, 487). Imajući to u vidu, oni zaključuju da se „koncept 'insulatora' čini sigurnim u TRBK, kao i da bi bilo interesantno videti detaljnije komparativne $\mathrm{i}$ teorijske studije o ulozi insulatora $\mathrm{i}$ kompleksnostima koje ova uloga generiše u vođenju politike“ (Buzan and Wæver 2003, 487). Ovaj rad je bio pokušaj da se doprinese diskusiji o insulatorima i daljem razvijanju i preciziranju pojmovno-kategorijalnog aparata TRBK. U radu je predstavljen koncept insulatora i predložena njegova nadogradnja uvođenjem razlikovanja pasivnog $i$ aktivnog insulatora. Kako je diskutovano, pasivni insulator $u$ ovakvoj podeli predstavlja tradicionalnog, odnosno uobičajenog insulatora koji razdvaja bezbednosne dinamike okolnih kompleksa, apsorbujući njihove energije. Za razliku od njega, aktivni insulator je onaj koji više emituje energiju, koji je važan činilac u bezbednosnim dinamikama susednih kompleksa, ali ne $\mathrm{u}$ dovoljnoj meri da ih ujedini $\mathrm{u}$ jedan jedinstveni. Uvođenje ovakve dihotomije ima i analitičko-prediktivnu funkciju jer postojanje aktivnog inuslatora sugeriše moguću transformaciju kompleksa, odnosno ukazuje na potencijal za integraciju ili dezintegraciju određenih (pod)regiona. Koncept insulatora je $\mathrm{u}$ radu težišno propitivan razmatranjem statusa Turske u TRBK, kao izrazito aktivnog insulatora. Predložena klasifikacija insulatora inicijalno je testirana i kroz skiciranje primene na druge države koje su Buzan i Vejver klasifikovali kao insulatore, poput Mjanmara, Nepala, Avganistana i Mongolije, koji se u sadašnjim okolnostima mogu okarakterisati kao pasivni insulatori. 


\section{BIBLIOGRAFIJA}

Abramowitz, Morton and Henry J. Barkey. 2009. “Turkey's Transformation. The AKP Sees Big". Foreign Affairs 88 (6): 118-128.

AlJazeera. 2021. "Purchase of Russian S-400 a 'done deal', Turkey tells US" March 24. https:/ / www.aljazeera.com/news/2021/3/24/turkey-tellsus-at-nato-russian-defence-purchase-is-done-deal

Antonenko, Oksana. 2008. The Shanghai Cooperation Organization and Central Asia's Security Dilemmas. London: Routledge.

Ayoob, Mohammed. 1999. "From Regional System to Regional Society:

Exploring Key Variables in the Construction of Regional Order". Australian Journal of International Affairs 53 (3): 247-260.

Barrinha, André. 2014. “The Ambitious Insulator: Revisiting Turkey's Position in Regional Security Complex Theory". Mediterranean Politics 19 (2): 165-182.

Basit, Saira H. 2018. "India-Myanmar Relations and the Management of Transnational Militant Threats". Journal of Strategic Security 11 (2): 73-92.

BBC. 2021. "Turkey blames EU in 'sofagate' diplomatic spat", April 8. https://www.bbc.com/news/56676344

Buzan, Barry and Gowher Rizvi. 1986. South Asian Insecurity and the Great Powers. London: Macmillan.

Buzan, Barry and Ole Wæver. 2003. Regions and Powers: the Structure of International Security. Cambridge: Cambridge University Press.

Buzan, Barry, Ole Weaver and Jaap de Wilde. 1998. Security: A New Framework for Analysis. London: Lynne Rienner.

Buzan, Barry. 1983. People, States and Fear. Brighton: Wheatsheaf.

Buzan, Barry. 1991. People, States and Fear: An Agenda for International Security Studies in the Post-Cold War Era. Hemel Hempstead: Harvester Wheatsheaf.

Deutsch, Karl W., Sidney A. Burrell, Robert A. Kann, Maurice Lee Jr., Martin Lichterman, Raymond E. Lindgren, Francis L. Loewenheim and Richard W. Van Wagenen, eds. 1957. Political Community and the North Atlantic Area: International Organization in the Light of Historical Experience. Princeton: Princeton University Press. 
Diehl, Paul F. and Joseph Lepgold. 2003. Regional Conflict Management. Oxford: Rowman \& Littlefield.

Diez, Thomas. 2013. "Insulator, bridge, regional center?: Turkey and regional security complexes". In: Debating Security in Turkey: Challenges and Changes in the Twenty-first Century, edited by Ebru Canan-Sokullu, 45-57. Lanham: Lexington Books.

Ejdus, Filip and Marko Kovačević. 2019. "Penetration, Overlay, Governmentality: The Evolving Role of NATO in the Western Balkan Security Dynamics". Journal of Intervention and Statebuilding 13 (5): 566-580.

Ejdus, Filip. 2006. Trojanski konj na pragu Evrope? Tursko članstvo u EU $i$ evropska bezbednost. Beograd: Beogradski centar za bezbednosnu politiku.

[EEAS] European Union External Action Service. 2021. “EU-Turkey relations: the need to build bridges", March 30. https:// eeas.europa.eu/ headquarters/headquarters-homepage/95930/eu-turkey-relationsneed-build-bridges_en

[EP] European Parliament. 2021. European Parliament resolution of 20 January 2021 on the implementation of the Common Security and Defence Policy - annual report 2020, 2020/2207(INI). https:// www.europarl.europa.eu/doceo/document/TA-9-2021-0013_EN. html\#def_1_1

Friedberg, Aaron. 1994. "Ripe for Rivalry: Prospects for Peace in a Multipolar Asia". International Security 18 (3): 5-33.

Gleditsch, Kristian. 2002. All International Politics is Local: the Diffusion of Conflict, Integration and Democratization. Ann Arbor: University of Michigan Press.

Glodić, Duško. 2011. „,Turska kao faktor regionalne saradnje sa državama obuhvaćenim procesom stabilizacije i pridruživanja“. Politeia 1 (2): 109-121.

Graham, Kennedy and Tania Felıcio. 2006. Regional Security and Global Governance: a Study of Interactions between Regional Agencies and the UN Security Council with a Proposal for a Regional: Global Security Mechanism. Brussels: VUB Brussels University Press.

Haas, Ernst. 1958. The Uniting of Europe: Political, Social, and Economic forces, 1950-1957. Stanford: Stanford University Press. 
Irish, John and Michel Rose. 2020. "France accuses Turkey of sending Syrian jihadists to Nagorno-Karabakh", Reuters, October 1. https:// www.reuters.com/article/us-armenia-azerbaijan-putin-macron/ france-accuses-turkey-of-sending-syrian-mercenaries-to-nagornokarabakh-idUSKBN26L3SB

Jervis, Robert. 1982. "Security Regimes". International Organization 36 (2): 357-378.

Jervis, Robert. 1989. The Meaning of the Nuclear Revolution. Ithaca: Cornell University Press.

Kacowicz, Arie M. 1997. “Third World Zones of Peace”. Peace Review 9 (2): 169-176.

Kanat, Kilic B. and Jackson Hannon. 2017. "Turkey-Israel Relations in the New Era: Opportunities and Challenges". Mediterranean Quarterly 28 (4): 64-86.

Katzenstein, Peter 2005. A World of Regions: Asia and Europe in the American Imperium. Ithaca: Cornell University Press.

Keohane, Robert. 1984. After Hegemony. Princeton: Princeton University Press.

Köstem, Seçkin. 2020. “Russian-Turkish cooperation in Syria: geopolitical alignment with limits". Cambridge Review of International Affairs 33: 1-23.

Lake, David A. and Patrick M. Morgan. 1997. Regional Orders: Building Security in a New World. University Park: Pennsylvania State University Press.

Marković, Miloš B. 2011. „Strategijska dubina - međunarodni položaj Turske: 2. poglavlje knjige". Politeia 1 (2): 189-215.

Mearsheimer, John J. 2001. The Tragedy of Great Power Politics. New York: Norton.

Milenković, Mirjana. 2020. Zapadni Balkan kao potkompleks u teoriji regionalnog bezbednosnog kompleksa. Doktorska disertacija. Fakultet političkih nauka, Univerzitet u Beogradu.

Mitrany, David. 1966. A Working Peace System. Chicago: Quadrangle Books.

Morgenthau, Hans. 1984. Politics Among Nations: the Struggle for Power and Peace. New York: Alfred a Knopf.

Muftuler-Bac, Meltem. 2000. “Turkeys Role in the EU's Security and Foreign Policies". Security Dialogue 31 (4): 489-502. 
Ngoma, Naison. 2005. Prospects for a Security Community in Southern Africa: an Analysis of Regional Security in the Southern African Development Community. Pretoria: Institute for Security Studies.

Nye, Joseph. 1971. Peace in Parts: Integration and Conflict in Regional Organization. Boston: Little Brown.

Oskanian, Kevork. 2008. "Of 'Friends' and 'Enemies': Expanding the Amity/Enmity Variable within Regional Security Complex Theory". Paper presented at the Annual Convention of the International Studies Association, San Francisco, USA, March 26-29.

Panarmenian. 2010. "Israel defined as major threat in Turkey's Red Book", October 31. http://www.panarmenian.net/eng/world/news/56075/.

Pavlović, M. Đorđe. 2016. „Odbrambena saradnja Srbije i Turske kao pokazatelj sprovođenja Davutogluove 'Strategijske dubine'“. Vojno delo 68 (3): 94-107.

Pierini, Marc. 2021. "The Price of a Positive EU-Turkey Agenda", Carnegie Europe, March 2. https://carnegieeurope.eu/strategiceurope/83969

Pugh, Michael and Waheguru Sidhu. 2003. The United Nations and Regional Security. London: Lynne Rienner.

Rainer, Elise and Anish Goel. 2020. “Self-Inflicted Instability: Myanmar and the Interlinkage between Human Rights, Democracy and Global Security". Democracy and Security 16 (4): 334-350.

Reuters. 2021. "Myanmar junta says no ASEAN envoy visit until stability restored", May 7. https://www.reuters.com/world/asia-pacific/ myanmar-junta-says-seeks-stability-before-allowing-asean-envoy-visit2021-05-07/

Simić, Dragan. 2002. Nauka o bezbednosti: savremeni pristupi bezbednosti. Beograd: Službeni list.

Singer, Max and Aaron Wildavsky. 1993. The Real World Order: Zones of Peace, Zones of Turmoil. Chatham: Chatham House.

Staff, Toi. 2020. “After years of acrimony, Turkey's Erdogan says he'd like better ties with Israel", The Times of Israel, December 25. https:/ / www.timesofisrael.com/after-years-of-acrimony-turkeyserdogan-says-hed-like-better-ties-with-israel/

Tanasković, Darko. 2010. Neoosmanizam - povratak Turske na Balkan. Beograd: Službeni glasnik. 
Tanasković, Darko. 2021. Pusto tursko. Beograd i Novi Sad: Institut za političko umrežavanje, Institut za evropske studije i Informatika AD.

Taspinar, Ömer. 2008. Turkey's Middle East Policies: Between Neo-Ottomanism and Kemalism. Washington: Carnegie Middle East Center.

The Jerusalem Post. 2010. "Turkish document defines Israel as central threat", October 30. http://www.jpost.com/Headlines/Article.aspx? id=193321

Ulusoy, Kivanç. 2020. “Turkey and Israel: Changing Patterns of Alliances in the Eastern Mediterranean". Journal of Balkan and Near Eastern Studies 22 (3): 415-430.

UN News. 2018. "Myanmar military leaders must face genocide charges UN report", August 27. https://news.un.org/en/story/2018/08/ 1017802

UN News. 2020. “Top UN court orders Myanmar to protect Rohingya from genocide" January 2020. https://news.un.org/en/story/2020/01/ 1055841

Väyrynen, Raimo. 1984. "Regional Conflict Formations: An Intractable Problem of International Relations". Journal of Peace Research 21 (4): 337359.

Väyrynen, Raimo. 2003. "Regionalism: Old and New". International Studies Review 5 (1): 25-51.

Yinglun, Shi. 2018. “Turkey, Russia vow to enhance strategic partnership", Xinhua, August 14. http://www.xinhuanet.com/english/2018-08/14/ c_137389957.htm 


\section{THE CONCEPT OF INSULATOR IN THE REGIONAL SECURITY COMPLEX THEORY}

Abstract: This paper focuses on the concept of insulator in the Regional Security Complex Theory (RSCT), as the original contribution of Buzan and Wæver to security studies. The introduction of the concept of insulator was necessary to overcome the difficulty in determining the borders between the regions (complexes), that is, to explain the different actions of the units (primarily countries) in relation to the regional security complex to which they do not belong. The aim of this paper is to further examine and upgrade the concept of insulator in the RSCT by introducing the distinction between passive and active insulators. The passive insulator in this dichotomy is a traditional, ordinary insulator, which separates the security dynamics of the surrounding complexes by absorbing their energies. In contrast, an active insulator is one that emits (security) energy, which is an important factor in the security dynamics of neighboring complexes but not strong enough to unite them into a single one. In addition to contributing to the further development and refinement of the conceptual-terminological apparatus of the RSCT, the introduction of such a dichotomy also has an analytical-predictive function because the existence of an active insulator may suggest a possible transformation of the complex, i.e., it indicates the potential for integration or disintegration of certain (sub)regions. In this paper, the concept of insulator is primarily discussed by using the case of Turkey, while the novel classification of insulators is initially tested by sketching the application to other countries that Buzan and Wæver have labelled as insulators.

Keywords: regional security, security theories, Buzan, Wæver, security complex, security sub-complex, insulator, buffer zone, Turkish foreign policy. 